\title{
Preventive and curative control of sclerotium rot disease of cocoyam cormel (Colocasia esculenta [L., Scott]) using plant extracts and Trichoderma koningii
}

\author{
Nwauzoma Akagbuo Bartholomew*, Jaja Tamunodiari Emylia, Njoku Chibuzor \\ Department of Plant Science \& Biotechnology, Rivers State University, Nkpolu-Oroworukwo, Port Harcourt, Nigeria.
}

\begin{tabular}{|c|c|}
\hline ARTICLE INFO & ABSTRACT \\
\hline $\begin{array}{l}\text { Article history: } \\
\text { Received on: June } 28,2017 \\
\text { Accepted on: August } 06,2017 \\
\text { Available online: November } 09,2017\end{array}$ & $\begin{array}{l}\text { Aqueous leaf extracts from air-dried samples of Carica papaya, Chromolaena odorata, and Azadirachta indica were } \\
\text { screened for antifungal properties against Sclerotium rolfsii at } 50,70 \text {, and } 100 \% \text { concentrations and Trichoderma } \\
\text { koningii }\left(4.9 \times 10^{6} \text { spores } / \mathrm{ml}\right) \text { in vivo. Dithane M } 45 \text { at } 2 \% \text { concentration was used as positive control for better } \\
\text { comparison. The aqueous extracts and T. koningii were applied as preventive and curative methods by spraying fresh }\end{array}$ \\
\hline $\begin{array}{l}\text { Key words: } \\
\text { Sclerotium rolfsii, } \\
\text { Colocasia esculenta, } \\
\text { Plant extracts, } \\
\text { Curative, } \\
\text { Preventive control }\end{array}$ & $\begin{array}{l}\text { and healthy cormels with } S \text {. rolfsii }\left(3.75 \times 10^{5} \text { spores } / \mathrm{ml}\right) \text {. The results showed that Mancozeb and } T \text {. koningii had } \\
\text { significant effect (preventive and curative) on disease severity and percentage weight loss. Furthermore, preventive } \\
\text { and curative application of } T \text {. koningii significantly reduced disease severity. C. papaya at } 50 \% \text { concentration } \\
\text { (preventive method) had the highest disease severity }(3.8 \%) \text {, as to the control }(4.0 \%) \text {. The extracts and dithane } \\
\text { M45 were more effective as curative, while } T \text {. koningii was better as preventive method. The result on percentage } \\
\text { weight loss showed that } C \text {. odorata }(70 \% \text { concentration) had the highest }(49.61 \%) \text {, followed by } C \text {. papaya }(50 \%) \\
\text { with } 47.85 \% \text {, and the least was } A \text {. indica }(23.77 \%) \text { at } 70 \% \text {. C. odorata and } \text { A. indica } 50 \% \text { and } 100 \% \text { concentrations, } \\
\text { respectively, significantly reduced weight loss, while } C \text {. odorata }(100 \% \text { concentration) and the control gave the } \\
\text { highest percentage weight loss in the curative method. Conclusively, plant extracts and } T \text {. koningii were more } \\
\text { effective in controlling the disease and reduction in weight loss than mancozeb. }\end{array}$ \\
\hline
\end{tabular}

\section{INTRODUCTION}

Cocoyam is a perennial monocotyledonous and herbaceous plant of the family Araceae. It is an important staple food in many developing countries in Africa, Asia, and the Pacific [1]. In Sub-Saharan Africa, cocoyam production is essentially by small-scale, resource-poor farmers (mostly female) with minimal agricultural input. Cocoyam is consumed mostly by the low-income earners and the economically vulnerable groups [1]. The two most commonly cultivated species are Colocasia esculenta (the red type or taro) and Xanthosoma sagittifolium (the white type or tannia). In Nigeria, cocoyam is mainly cultivated for the edible corms as a source of carbohydrate to supplement yam and cassava as well as for medicinal purposes $[2,3]$. Cocoyam ranks third in importance after cassava and yam among the root and tuber crops cultivated and consumed in Nigeria. Cameroon, Ghana, and Nigeria account for over $60 \%$ of the global cocoyam production [1]. Cocoyam tolerates shady environments, often

*Corresponding Author

Nwauzoma Akagbuo Bartholomew,

Department of Plant Science \& Biotechnology,

Rivers State University, Nkpolu-Oroworukwo,

Port Harcourt, Nigeria.

Email:drnwabarth@yahoo.com intercropped with perennial cash crops such as cocoa, bananas, and oil palms.

Harvested cocoyam is stored by different methods to extend the shelf life for use in the next planting season and food. Post-harvest loss of root and tuber crops has been a very serious problem to farmers as more than $40 \%$ of their harvest may be lost because of decay [4]. Organisms associated with cocoyam rot in Nigeria include Aspergillus flavus, Penicillium digitatum, Botryodiplodia theobromae, Sclerotium rolfsii, Fusarium solani, and Erwinia carotovora [5]. In particular, cocoyam cormel rot caused by $S$. rolfsii is common. S. rolfsii Sacc. is distributed in tropical and subtropical regions of the world with high temperatures [6]. Symptoms due to $S$. rolfsii in host plants include seed rot, seedling blight, collar rot, stem rot, and wilt resulting to economic losses. Management of $S$. rolfsii is difficult due to its wide host range and the ability of sclerotia to survive between 3 and 4 years in the soil [7]. The goal of plant disease management is to reduce the economic and esthetic damage caused by plant diseases. Chemical control of rot diseases in crops is feasible but not without identifiable problems such as chemical residues, biodegradation, phytotoxicity, development of resistance in target organism, and high cost [8].

Natural plant products are potential alternatives to chemical fungicides in plant disease management. Carica papaya (family: Caricaceae) is an 
unbranched small tree cultivated in the tropical regions for the edible fruits. C. papaya is used as food and in medicine. C. papaya contains various types of biologically active compounds with the two important compounds as chymopapain and papain. [9,10] reported that the extracts of papaya leaves inhibited the growth of Rhizopus stolonifer. Formulations of C. papaya roots, Mangifera indica leaves, Citrus limon fruit, and leaf have also been reported to possess antibacterial activity against species of Salmonella [11]. Azadirachta indica (Neem, family Meliaceae) is a tropical tree commonly found in Asia and Africa, but native to India, Bangladesh, Pakistan, and Myanmar [12]. Its local names include Dogon Yaro (Nigeria), Azad Dirkht (Persian), and Neeb (Arabic). Several authors have reported the medicinal uses and phytotoxicity of $A$. indica, where extracts from the seed have been reported to greatly reduce conidial germination in several fungi [13]. Chromolaena odorata (family Asteraceae) is a perennial weed shrub of crops and pastures found mainly in West Africa and South Asia [14]. A decoction prepared from the aqueous extract of the leaves of $C$. odorata has been licensed for clinical use in Vietnam. [14] reported that aqueous leaf extracts of $C$. odorata showed antimicrobial and anticoagulation effects in clinical studies. The same leaf extracts have been used as cough remedy and as an ingredient with leaf extracts of guava and lemongrass for the treatment of malaria. $[15,16]$ reported that fresh leaves have been traditionally used in most tropical countries like Vietnam for the management of burn wounds, dentoalveolitis, soft tissue wounds, leech bite, and skin infection. There are confirmed reports that leaves and stems of $C$. odorata contain steroids, essential oils, flavonoids, and triterpenes [17]. The antagonistic activities of Trichoderma koningii against plant pathogenic fungi are welldocumented [18]. However, reports on their efficacy on the control of rots caused by S. rolfsii are sparse. Therefore, the objective of the present study is to evaluate the antifungal properties of leaf extracts of C. papaya, C. odorata and A. indica, T. koningii (a biocontrol agent), and standard fungicide - Dithane M-45 (Mancozeb) in the management of cocoyam cormel rot disease caused by the pathogen S. rolfsii.

\section{MATERIALS AND METHODS}

\subsection{Source of Materials}

Fresh and healthy cocoyam cormels and cormels showing symptoms of post-harvest rot were obtained from Mile 1 market located at the city center in Port Harcourt, Nigeria, in sterile polythene bags. Dithane M-45 commonly called mancozeb was also obtained from School to Land Authority of the Rivers State Government. Fresh leaves of A. indica, C. papaya, and C. odorata were obtained from a village in Etche Local Government Area of Rivers State, Nigeria and authenticated in the Department of Applied and Environmental Biology, Rivers State University of Science and Technology, Port Harcourt, where voucher specimens of the plants were deposited. T. koningii was graciously supplied by the Advanced Plant Pathology Laboratory, International Institute for Tropical Agriculture (IITA), Ibadan.

\subsection{Preparation of Plant Extracts and Pathogenicity Test}

Fresh leaves of $C$. papaya, C. odorata, and A. indica were dried at room temperature for 1 week and later ground into very fine powder using laboratory mortar and pestle and stored separately in sterile plastic containers. An aqueous solution of the dried plant samples was prepared by mixing $1 \mathrm{~g}$ of each leaf powder with $100 \mathrm{ml}$ of sterile distilled water, stirred vigorously and kept for $24 \mathrm{~h}$. The extracts were then decanted, filtered through a Whatman filter paper and used within $24 \mathrm{~h}$ of preparation. The $100 \%$ concentration from each extract was serially diluted to obtain $50 \%$ and $70 \%$ concentration. Cocoyam cormels showing symptoms of rot were surface sterilized in $5 \%$ sodium hypochlorite and rinsed thrice in sterile distilled following the method of [19]. Approximately $2 \mathrm{~mm}$ size bearing infected and healthy portions of the cocoyam cormel were cut using a sterilized scalpel, surface sterilized with $5 \%$ sodium hypochlorite, rinsed in sterile distilled water, dried between sheets Whatman filter paper and inoculated onto Potato Dextrose Agar in Petri dishes. The plates were incubated at $28 \pm 2{ }^{\circ} \mathrm{C}$ for 4 days and the resulting fungal growth was sub-cultured by transferring hyphal tips from the edge of each colony onto fresh PDA plates to obtain a pure culture of the organism. Pathogenicity test was done by cutting about $5 \mathrm{~mm}$ mycelial disk from a 6-day-old pure culture of $S$. rolfsii, mixed with 3.9 g PDA broth in $100 \mathrm{ml}$ sterile distilled water and incubated for 7 days. Then, the mixture was filtered using Whatman filter paper and transferred into $50 \mathrm{ml}$ distilled water containing $10 \%$ glucose, properly agitated, and sprayed on fresh surface sterilized healthy cocoyam cormels and kept at $28 \pm 2{ }^{\circ} \mathrm{C}$. Symptoms of rot started appearing 7 days after inoculation and $S$. rolfsii was reisolated from the infected cormel with physical properties confirming the pathogen.

\subsection{In Vivo Tests and Disease Severity}

The aim of this trial was to examine the preventive and curative effects of the plant extracts, T. koningii and the synthetic fungicide on disease severity and weight loss in cocoyam cormels due to $S$. rolfsii. The treatments consisted of three plant extracts at (50,70, and 100\%) concentrations, dithane M45 (mancozeb), and T. koningii laid out in a completely randomized design. The curative method was done by growing three mycelial disks ( $5 \mathrm{~mm}$ each) of $S$. rolfsii from a 6-day-old pure culture for 7 days in a PDA broth containing $17 \mathrm{~g}$ of PDA mixed in $400 \mathrm{ml}$ sterile distilled water. The culture was filtered using Whatman filter paper and transferred into $300 \mathrm{ml}$ distilled water containing $10 \%$ glucose. The mixture was properly agitated and sprayed on the freshly cut surface of healthy cocoyam cormels at $10 \mathrm{ml}$ per cormel. After 2 days, 50, 70, and $100 \%$ concentration of each plant extract were sprayed on the cormels. The preventive assay was performed in the same way, except that the plant extracts were applied 3 days before the inoculation of the pathogen. For the fungicide mancozeb, $10 \mathrm{ml}$ was measured from a $2 \%$ concentration and applied on the freshly cut surface of healthy cocoyam cormels, 3 days after and before the application of the pathogen, to constitute the curative and preventive assays, respectively. In the case of the biocontrol agent, $5 \mathrm{~mm}$ disk of a 6-day-old pure culture of $S$. rolfsii (pathogen) and T. koningii (biocontrol agent) was grown separately in PDA broth containing $3.9 \mathrm{~g}$ of PDA mixed in $100 \mathrm{ml}$ sterile distilled water for 7 days. Each culture was filtered separately in Whatman filter paper and transferred into $50 \mathrm{ml}$ distilled water containing $10 \%$ glucose. The mixtures were properly agitated and $3.75 \times 10^{5}$ spores/cell of $S$. rolfsii was sprayed on freshly cut surface of healthy cocoyam cormels using hemocytometer. Furthermore, $4.9 \times 10^{6}$ spores $/ \mathrm{ml}$ of $T$. koningii was sprayed on the cormels before and after 3-day following the application of the pathogen to constitute the "curative" and "preventive" methods, respectively. Cormels sprayed with $S$. rolfsii only served as negative control. All the treatments were kept at laboratory temperature for 14 days and replicated thrice.

The severity of the infection was scored on a 5-point scale of 0-4, 14 days after incubation; where: $0=$ no infection; $1=$ slight infection; $2=$ moderate infection ( $50 \%$ of cormel infected); $3=$ severe infection ( $75 \%$ of cormel infected); and $4=$ complete rot (100\% infection), 
according to [3]. Furthermore, percentage weight loss of cormel, 14 days after inoculation was calculated as:

$\%$ weight loss $=(\mathrm{IW}-\mathrm{FW} / \mathrm{IW}) \times 100 / 1$

IW = Initial weight before inoculation

$\mathrm{FW}=$ Final weight after inoculation .

All data obtained were statistically analyzed using analysis of variance and means separated using Duncan's multiple range test at 5\% level of significance.

\section{RESULTS AND DISCUSSION}

\subsection{Disease Severity}

The results indicate that the plant extracts, mancozeb (dithane M45) and $T$. koningii had varying significant preventive and curative effects on disease severity and percentage weight loss in cocoyam cormels infected with $S$. rolfsii. As expected, disease severity was highest in the negative control compared to other treatments (Fig. 1). The application of $T$. koningii as a preventive measure significantly reduced disease severity. It also had the same effect when applied as curative measure, but this was not significantly different from other methods of control (Fig. 1). A higher disease severity was observed in C. papaya at $50 \%$ concentration comparable to the control. The result further shows that the plant extracts and the fungicide were more effective as curative, while $T$. koningii was more effective in the preventive method. The differential activities of preventive and curative effects of plant extracts, essential plant oils, and fungicides on plant pathogens have been reported [14]. Furthermore, the activities of plant extracts and T. koningii as both protective and curative biocontrol agent have been reported by other workers [20,21]. [14] reported the protective effects of neem seed oil and dinocap (fungicide) on Erysiphe cichoracearum, the causal pathogen of okra powdery mildew in detached leaf-disk assay and in potted plants in Egypt. The same authors showed that neem seed oil showed a high curative effect and decreased disease severity, improved plant growth and pod yield in okra. The low disease severity recorded in T. koningii for this work especially as preventive method, suggests that this antagonist should be applied before the appearance of symptoms under field conditions for effective management of $S$. rolfsii in cocoyam cormels. In general, curative method reduced $S$. rolfsii severity than preventative method in all treatments, but for the biocontrol agent (Fig. 1). The efficacy of $T$. koningii as a biocontrol agent in the management of cocoyam cormel rot caused by $S$. rolfsii was $<25 \%$ of the cormel showed signs of rot. Furthermore, A. indica ( $100 \%$ concentration) had disease severity score of 2, while severity score for C. papaya and dithane M-45 was 3, in each case (Plate 1). Thus, T. koningii reduced cocoyam rot compared to the other treatments. The metabolites produced by T. koningii with antagonistic property against plant pathogens could serve as alternative method to the popular fungicides used in the control of cocoyam diseases.

\subsection{Weight loss Assessment}

The effect of the various treatments applied either as curative or preventive method on percentage weight loss in cocoyam cormel rot is shown in Fig. 2. The inoculated control had the highest (46.51\%) percentage weight loss of in both methods. Aside the negative control and $C$. odorata at $100 \%$ concentration, weight loss was lower in the curative than preventive method assays. The application of $C$. odorata at $50 \%$ and $\mathrm{A}$. indica at $100 \%$ concentrations as curative method resulted to significant reduction in cormels weight, while $C$. odorata at $100 \%$ concentration and the negative control gave the highest percentage weight loss. There were no significant differences in the other treatments (Fig. 2). However, this was completely different from the preventive method where no significant difference was observed in all the treatments including the control. However, C. odorata at $70 \%$ concentration gave the highest (49.61) percentage weight loss. This was followed by $C$. papaya at $50 \%$ concentration with $47.85 \%$ and the least $(23.77 \%)$ was $A$. indica at $70 \%$ concentration (Fig. 2). Therefore, the curative method revealed the effects of the

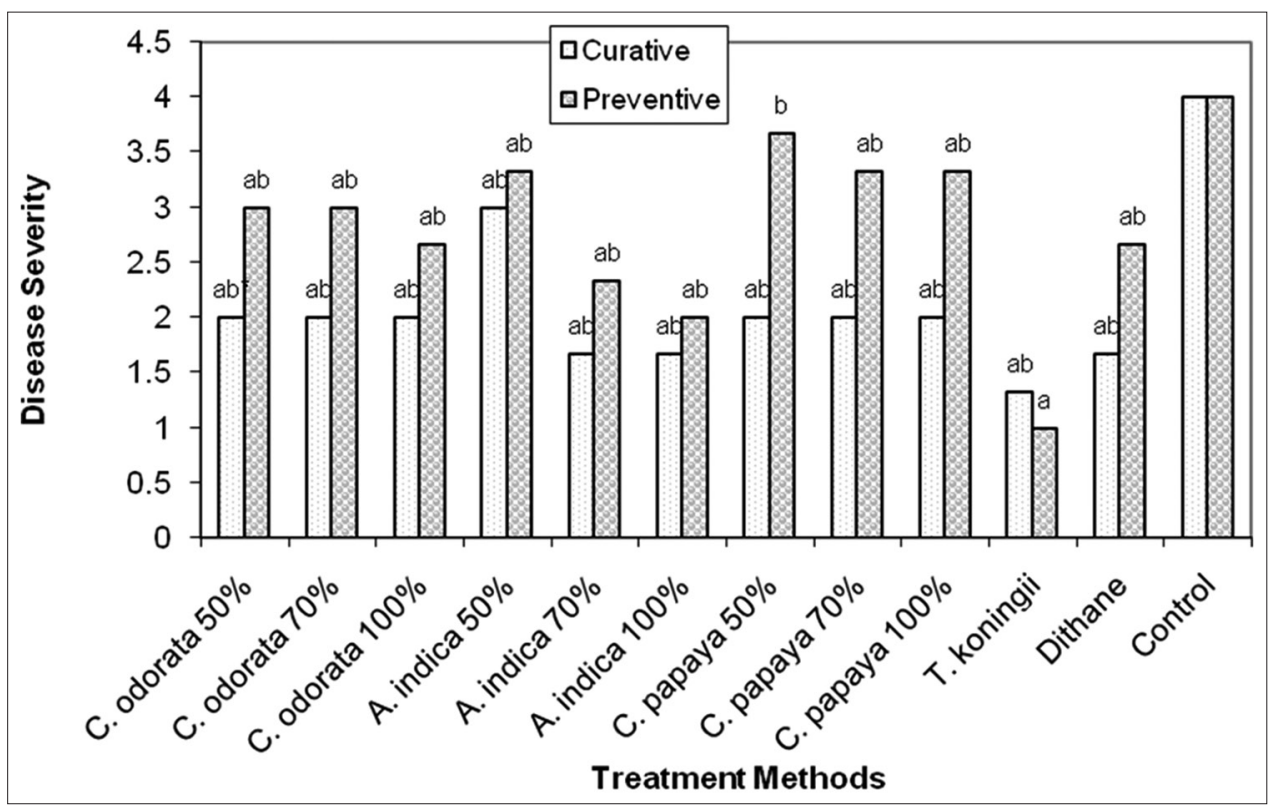

Fig. 1: Curative and preventive effects of leaf extracts of Chromolaena odorata, Azadirachta indica, Carica papaya, Trichoderma koningii, and dithane M45 on rot development in cocoyam cormels after 14 days incubation. *Mean values per treatment followed by the same letter are not significantly different $(P \leq 0.05)$. 


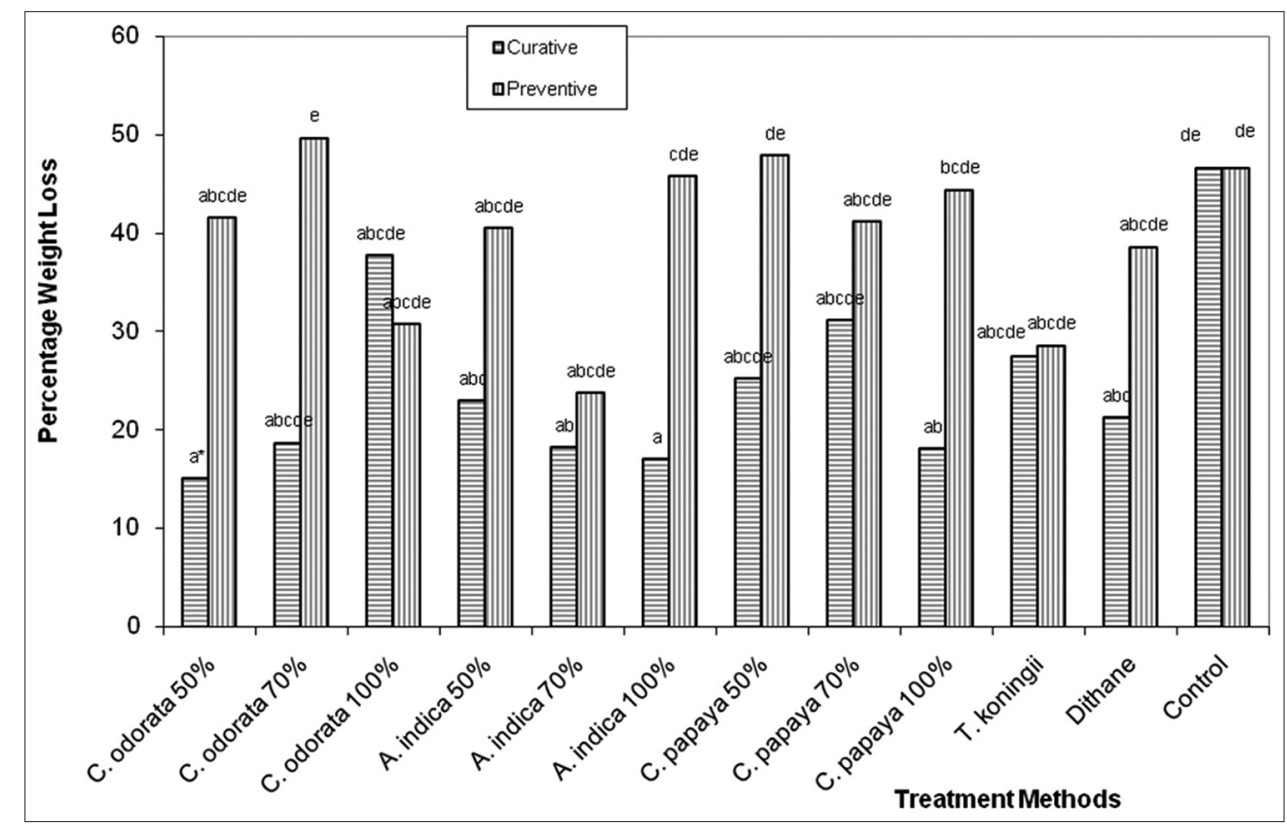

Fig. 2: Effects of curative and preventive treatments on percentage weight loss of cocoyam cormels after 14 days incubation. *Mean values per treatment followed by the same letter are not significantly different $(P \leq 0.05)$.

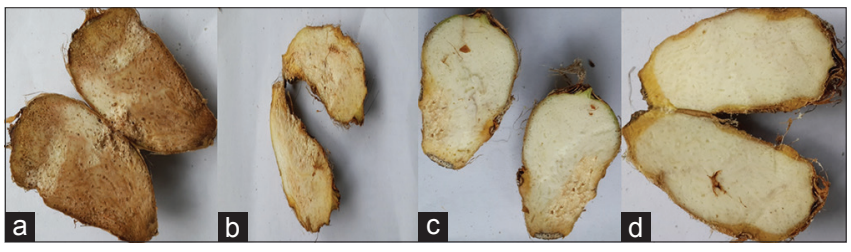

Plate 1: Cocoyam cormel showing different stages of rot. (a) 100\% rot (4),

(b) $75 \% \operatorname{rot}(3)$, (c) $50 \% \operatorname{rot}(2)$, (d) $25 \% \operatorname{rot}(1)$.

different management methods on the weight of cormels affected by rot [22]. Reported that Cassia alata reduced weight loss and rot in cocoyam cormels in Enugu State, Nigeria. The significant reduction in percentage weight recorded in $A$. indica indicates that the plant possesses some positive bioactivities on rot causing organisms in cocoyam. Similar results on the reduction of weight loss using ashes from the bark of kola nut tree, neem tree, and inflorescence of oil palm have been reported [23].

\section{CONCLUSION}

Our study confirms that C. papaya, C. odorata, A. indica, and T. koningii possess potential inhibitory effect on the mycelia growth of $S$. rolfsii, the causal agent of cocoyam cormel rot. However, cormels treated with $T$. koningii gave the best performance in rot reduction. Therefore, C. papaya, C. odorata, A. indica, and T. koningii can be used to control $S$. rolfsii. Their effectiveness could be incorporated to form an integrated disease management strategy to control this pathogen. This will also reduce the risk of pesticide residues build-up and pathogens resistance to fungicides.

\section{ACKNOWLWDGMENTS}

The authors are grateful to Prof. D. B. Olufolaji for designing the experiment and the anonymous reviewers whose comments improved the quality of the paper.

\section{REFERENCES}

1. Onyeka J. Status of Cocoyam (Colocasia esculenta and Xanthosoma spp) in West and Central Africa: Production, Household Importance and the Threat from Leaf Blight. Lima (Peru): CGIAR Research Program on Roots, Tubers and Bananas (RTB); 2014. p. 32.

2. Eze CC, Maduewesi JN. Relation of traditional methods to the magnitude of storage losses of cocoyam (Colocasia esculenta (L) schott). Nig J Plant Protection 1990;13:26-34.

3. Nwachukwu EO, Osuji JO. Evaluation of plant extracts for antifungal activity against Sclerotium rolfsii causing cocoyam cormel rot in storage. Res J Agric Biol Sci 2008;4:787-93.

4. Olurinola PF, Ehinmidu JO, Bonire JJ. Antifungal activity of n-tributyltin acetate against some common yam rot fungi. Appl Environ Microbiol 1992;58:758-60.

5. Onuegbu BA. Composition of four cocoyam cultivars and their tolerance to corm rot. Trop Sci 1999;39:136-9.

6. Arunasri PT, Chalam NP, Redddy ST, Reddy BR. Investigations on fungicidal sensitivity of Trichoderma spp. and Sclerotium rolfsii (collar rot pathogen) in Crossandra. Int J Appl Biol Pharmaceut Tech 2011;2:290-3.

7. Maxwell DP. Oxalic acid production by Sclerotinia sclerotiorum in infected bean and in culture. Phytopathology 1970;60:1395-8.

8. Okigbo RN, Odurukwe CN. Occurrence and control of fungal rot pathogens of yam (Dioscorea rotundata poir) with leaf extracts of Chromolena odorata, Carica papaya and Aspilia africana. Nig J Mycol 2009;2:154-65.

9. Brocklehurst K, Salih E. Fresh non-fruit latex of Carica papaya contains papain multiple forms of chymopapain and papaya proteinase omega. Biochem J 1985;228:525-7.

10. Elisa FR, Jessica KK. Antibacterial activity of papaya leaf extracts against pathogenic bacteria. Makara J Technol 2011;15:84-5.

11. Nkuo-Akenji T, Ndip R, McThomas A, Fru EC. Anti-salmonella activity of medicinal plants from Cameroon. Cent Afr J Med 2001;47:155-8.

12. Gangulin S. "Neem" a therapeutic for all seasons. Curr Sci 2002;82:1304. 
13. Moharam MH, Obiadalla-Ali HA. Preventative and curative effects of several plant derived agents against powdery mildew disease of okra. Not Sci Biol 2012;4: 76-82.

14. Phan TT, Wang L, See P, Grayer RJ, Chan SY, Lee ST. Phenolic compounds of Chromolaena odorata protect cultured skin cells from oxidative damage: Implication for cutaneous wound healing. Biol Pharm Bull 2001;24:1373-9.

15. Vital PG, Rivera WL. Antimicrobial activity and cytotoxicity of Chromolaena odorata (L.) Extracts. J Med Plant Res 2009;3:511-8.

16. Nghiem DP. The Therapeutic Effects of the Extract from the Leaves of Eupatorium odoratum on the Infection Soft Tissue and NonHealing Wounds (PhD Thesis) 1992; Hanoi, Vietnam.

17. Wollenweber E, Dorr M, Muniappan R. Exudate flavonoids in a tropical weed, Chromolaena odorata. Biochem Syst Ecol 1996;23:873-4.

18. Olufolaji DB, Martins AA, Toyosi CA, Rowland M. Green Technologies for Sustainable Growth of Sugar and Integrated Industries in Developing Countries. China: Nanning, PR; 2014. p. 454-6.

19. Ritchie B. Practical Techniques in Plant Pathology. Wallingford U.K.: CAB; 1991.
20. Sung-Chul Y. Selection and a 3-year field trial of Sorangium cellulosum KYC 3262 against anthracnose in hot pepper. Plant Pathol J 2014;30:279-87.

21. Boungab K, Tadjeddine A, Belabid L, Fortas Z, Bassam B. Exploitation of some plant extracts for ecofriendly management of net blotch of Barley. J Chem Pharm Res 2015;7:732-9.

22. Eze SC, Ugwuoke KI, Ogbonna PE, Onah RN, Onyeonagu CC, Oyeke CC. Evaluation of indigenous technologies of fresh cocoyam (Colocasia esculenta) [(L.) (Schott)] in Southeastern Nigeria. Afr J Agric Res 2015;10:737-41.

23. Eze CS. Studies on Microbial Rotting of Cocoyam (Colocasia esculenta L.) in Storage at Nsukka. Ph.D. Thesis 1991, Nsukka, Nigeria: Department of Botany, University of Nigeria.

\section{How to cite this article:}

Nwauzoma AB, Jaja ET, Njoku C. Preventive and curative control of

sclerotium rot disease of cocoyam cormel (Colocasia esculenta [L.,

Scott]) using plant extracts and Trichoderma koningii. J App Biol Biotech.

2017;5(6):40-44. DOI: 10.7324/JABB.2017.50606 